\title{
Global Warming Potential of a New Waterjet-Based Recycling Process for Cathode Materials of Lithium-Ion Batteries
}

\author{
Leonard Kurz ${ }^{1, *}$, Mojtaba Faryadras ${ }^{1}$, Ines Klugius ${ }^{1}$, Frederik Reichert ${ }^{1, *}$, Andreas Scheibe ${ }^{1}$, Matthias Schmidt ${ }^{2}$ \\ and Ralf Wörner ${ }^{1}$ \\ 1 Institute for Sustainable Energy Technology and Mobility (INEM), Hochschule Esslingen—University of \\ Applied Sciences, Kanalstraße 33, 73728 Esslingen, Germany; mofags@hs-esslingen.de (M.F.); \\ Ines.Klugius@hs-esslingen.de (I.K.); Andreas.Scheibe@hs-esslingen.de (A.S.); \\ Ralf.Woerner@hs-esslingen.de (R.W.) \\ 2 Erlos GmbH, Reichenbacher Straße 67, 08056 Zwickau, Germany; Matthias.Schmidt@weckpluspoller.de \\ * Correspondence: Leonard.Kurz@hs-esslingen.de (L.K.); Frederik.Reichert@hs-esslingen.de (F.R.)
}

check for updates

Citation: Kurz, L.; Faryadras, M.; Klugius, I.; Reichert, F.; Scheibe, A.; Schmidt, M.; Wörner, R. Global Warming Potential of a New Waterjet-Based Recycling Process for Cathode Materials of Lithium-Ion Batteries. Batteries 2021, 7, 29. https://doi.org/10.3390/ batteries7020029

Academic Editor: Kai Peter Birke

Received: 1 April 2021

Accepted: 20 April 2021

Published: 1 May 2021

Publisher's Note: MDPI stays neutral with regard to jurisdictional claims in published maps and institutional affiliations.

Copyright: (c) 2021 by the authors. Licensee MDPI, Basel, Switzerland. This article is an open access article distributed under the terms and conditions of the Creative Commons Attribution (CC BY) license (https:// creativecommons.org/licenses/by/ $4.0 /)$.

\begin{abstract}
Due to the increasing demand for battery electric vehicles (BEVs), the need for vehicle battery raw materials is increasing. The traction battery (TB) of an electric vehicle, usually a lithiumion battery (LIB), represents the largest share of a BEV's $\mathrm{CO}_{2}$ footprint. To reduce this carbon footprint sustainably and to keep the raw materials within a closed loop economy, suitable and efficient recycling processes are essential. In this life cycle assessment (LCA), the ecological performance of a waterjet-based direct recycling process with minimal use of resources and energy is evaluated; only the recycling process is considered, waste treatment and credits for by-products are not part of the analysis. Primary data from a performing recycling company were mainly used for the modelling. The study concludes that the recycling of $1 \mathrm{~kg}$ of TB is associated with a global warming potential (GWP) of $158 \mathrm{~g} \mathrm{CO}_{2}$ equivalents $\left(\mathrm{CO}_{2} \mathrm{e}\right)$. Mechanical removal using a water jet was identified as the main driver of the recycling process, followed by an air purification system. Compared to conventional hydro- or pyrometallurgical processes, this waterjet-based recycling process could be attributed an 8 to 26 times lower GWP. With 10\% and 20\% reuse of recyclate in new cells, the GWP of TBs could be reduced by $4 \%$ and $8 \%$, respectively. It has been shown that this recycling approach can be classified as environmentally friendly.
\end{abstract}

Keywords: lithium-ion battery; traction battery; waterjet-based recycling; direct recycling; life cycle assessment; global warming potential

\section{Introduction}

Since the development of lithium-ion batteries (LIBs) in the 1970s, and due to the exclusive attributes of a long lifespan and high energy capacity, LIBs have grown to be important in the field of portable electronic devices [1,2]. In 2015, at least 5.6 billion LIB cells were traded globally [3,4], and the market size of LIBs has been predicted to grow by another 12\% from 2016 to 2024, achieving a market value of USD 56 billion by 2024 [3]. Due to their significantly higher energy density, economic, and ecological advantages over other cell technologies, LIBs are particularly suitable as traction batteries, and therefore are predestined to be used in electric vehicles. The shift from internal combustion engines (ICEs) to e-mobility is expected to lead to even greater increases in registrations of electrically powered vehicles in the coming years. Kosai et al. claimed that, by 2050, up to 56 million battery electric vehicles (BEVs) are expected to be registered, 28 times as many as in 2016, which increases the demand for LIBs significantly [5].

After reaching their end of life (EOL), because they become hazardous materials in the waste stream of the environment, EOL LIBs need to be managed responsibly [6,7]. In Europe, between the years 2013 and 2014, the LIB market reported a total consumption of 65,500 tons of LIBs [8], while only about 1900 tons was recycled in the same period [3]. 
In another report, Wang et al. [9] claimed that the number of waste LIBs in vehicles that would need to be recycled, in an optimistic case, would be 6.76 million in 2035. Through a combination of innovations in recycling technologies and proactive regulations regarding collection and disposal of spent batteries, a significant fraction of the materials required for production of new LIBs could be supplied by EOL LIBs [10]. With the recently published proposal concerning batteries and waste batteries, the European Union (EU) aims to boost the circular economy of the battery value chain to reduce the environmental impact of batteries. To achieve this, the EU is striving for directives that set minimum rates for the recycling of EOL batteries and usage of recyclate within the production of new batteries for the EU market [11]. Therefore, the development of applicable technologies for LIB recycling, to recover particularly the elements that are low in the earth crust, are necessary [9]. Another aim of recycling LIBs is to keep hazardous materials from entering landfills [12] and to close the loop of raw materials utilized in LIBs for long-term sustainability and resource conservation [13]. In other words, since recycling processes enable internal material flows, it is considered to be a fundamental aspect of the circular economy [3].

Apart from reusing the batteries, recycling of LIBs can be categorized into the following three different technologies [9], used alone or in combination-namely, hydrometallurgy (e.g., retrieve technologies); pyrometallurgy (e.g., Umicore); and direct recycling (example-On to tech) $[10,14,15]$, as shown in Figure 1. The pretreatment process includes discharging by immersing in a salt solution (e.g., $\mathrm{NaCl}$ ), dismantling, which must be done in a sealed environment for safety reasons, and separating of damaged spent LIBs [9]. The hydrometallurgy route involves the leaching of valuable elements from a solid matrix into ions formed in a solution of inorganic or organic acid [16] and, subsequently, recovery of these metals by selective separation, electrochemical deposition, solvent extraction [16] into mono-metal material, or a precursor for the fabrication of new electrode materials $[9,17]$. Before hydrometallurgical treatment, the spent LIBs usually get shredded for an easier leaching procedure. The pyrometallurgical route is a smelting process which concentrates metal species such as $\mathrm{Co}, \mathrm{Cu}$, and $\mathrm{Ni}$ in the molten phase, while other constituents such as $\mathrm{Li}, \mathrm{Al}, \mathrm{Si}, \mathrm{Ca}$, and some $\mathrm{Fe}$ in the slag phase $[9,14]$. In order to obtain pure metals or metal salts, the slags are processed using the hydrometallurgical technique. In direct recycling, battery material is recovered without breaking it down into its components $[6,18]$. The aim is to reuse this material in new cells with minimal effort and without additional processes [6]. The most important battery material for direct recycling is considered to be the cathode material, as it is usually the most valuable component of an LIB cell with $33 \%$ of the total cost [19]. The most important question, however, is whether the recovered material can have comparable quality properties to virgin material [6]. While recovered material from direct recycling methods might not perform the same as primary material, however, compared to the hydrometallurgy and pyrometallurgy, direct recycling methods appear to be more environmentally friendly with lower amounts of emissions and energy consumption [10].

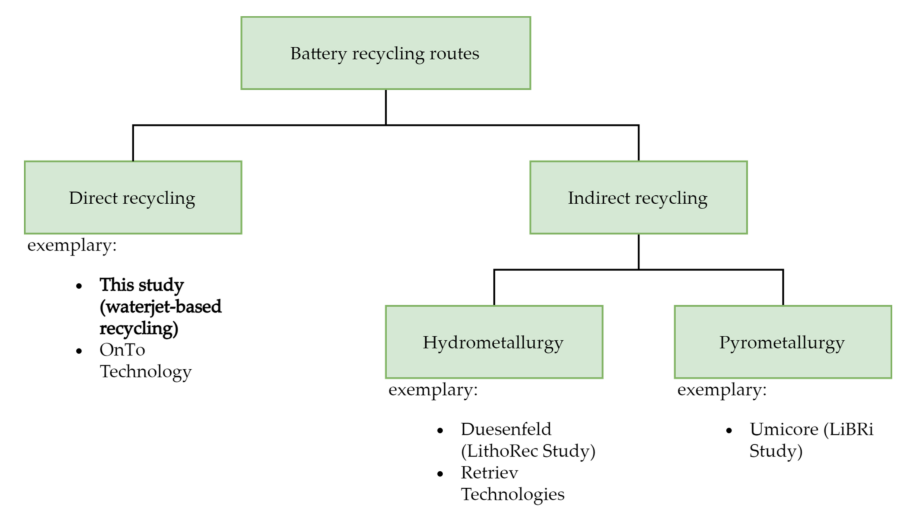

Figure 1. Battery recycling routes [20]. 
Beside these, recently, there have been other methods for battery recycling reported. These methods, include cathode healing, which combines two simple steps of hydrothermal processing of the spent cathode material followed by heat treatment in a cost-effective way [21], deagglomeration of polyvinylidene fluoride binder from cathode composite, which is based on a degree of surface hydrophobicity using the froth flotation method [14], and an oxalic coprecipitation method, which is a closed-loop regeneration method for $\mathrm{LiNi}_{5} \mathrm{Co}_{2} \mathrm{Mn}_{3} \mathrm{O}_{2}$ material of spent LIBs using mixed acid leaching, oxalate co-precipitation and solid-phase reaction [16].

Sieber et al. [17] claimed that, as we move into the future, resource- and energyinefficient hydrometallurgy and pyrometallurgy recycling methods must be avoided. Since there are no reports on waterjet-based battery recycling processes to the best of our knowledge, the here-presented procedure is new in the field of battery recycling. This new approach involves a waterjet-based direct recycling method (or functional recycling) with minimal use of chemicals and energy for separation of the cathode-coating layer, which contains $\mathrm{LiNi}_{\mathrm{x}} \mathrm{Mn}_{\mathrm{y}} \mathrm{Co}_{\mathrm{z}} \mathrm{O}_{2}(\mathrm{NMC})$, carbon black, and organic binder from the Al substrate foil, while preserving their chemical, physical, and morphological characteristics [17]. This recycling process does not use energy-intensive shredding or melting down of the cells, as is otherwise used in conventional recycling processes for LIBs. Instead, the process focuses on dismantling the battery and the cell itself as far as possible. The separated electrode then goes on a conveyor belt through a water jetting process, whereby the electrode coating is separated from the collector foil by a high-pressure water jet. The intention of this direct (or functional) recycling approach is to add recovered battery-grade cathode material to new NMC active material up to a certain proportion. Doose et al. [22] claimed that recycling processes must be flexible and adaptable to future cell chemistry and production technologies. Whether or not this waterjet-based recycling can meet these criteria, and can be used for production of new cells, must be examined.

In this study, this new waterjet-based direct recycling approach was ecologically evaluated with the help of a life cycle assessment (LCA) to evaluate its potential ecologic performance. The structure of this LCA is divided into four sections according to the standards DIN EN ISO 14040:2006 [23] and ISO 14044:2006 [24]-the objectives and methodology of the study, life cycle inventory (LCI), life cycle impact assessment (LCIA), and life cycle evaluation.

\section{Objectives and Methodology of the Study}

\subsection{Objective of the Study}

In November 2019, the joint project "Industrial Disassembly of Battery Modules and E-Motors to Secure Economically Strategic Raw Materials for E-Mobility (DeMoBat)" [25] was approved by the government of Baden-Wuerttemberg in Germany. The aim is, inter alia, to investigate the feasibility of a waterjet-based recycling process for traction batteries (TBs), to explore the limits of possible admixtures and to identify the potentials for reuse in the TB manufacturing process. Part of this project is to assess the environmental impacts of such an approach. Therefore, we modelled a waterjet-based recycling method for TBs to create an LCA, as well as to be able to draw conclusions about the environmental impacts associated with the recovered cathode coating. Furthermore, comparisons with indirect recycling processes should be made where possible, as well as to investigate possible impacts on new cathode coatings through different admixtures. The focus of this study is primarily based on the impact category of the global warming potential (GWP), which represents an excerpt from a complete LCA.

\subsection{Methodology of the Study}

\subsubsection{Product Sustainability Software: GaBi}

For modelling the LCI and calculating the LCIA, the GaBi product sustainability software tool from Sphera Solutions, Inc. (Chicago, IL, USA) with version 10.0.0.71 and the professional database was used. With the help of $\mathrm{GaBi}$, the preparation of the $\mathrm{LCI}$ and the 
determination of the LCIA was significantly simplified. After all processes were modelled, the desired method of impact assessment was selected from various available methods. $\mathrm{GaBi}$ assigned the impact indicator values taken from the LCI for the selected categories, calculated the corresponding values, and displayed the results [26].

\subsubsection{Function and Functional Unit}

The function of the system is the recovery of the cathode material of TBs according to the described waterjet-based recycling process. Therefore, the functional unit is defined as the recycling of one kilogram of TBs and the associated reference flow is defined as the path of the cathode material from one kilogram of TBs. The amount of cathode material depends on the battery composition. In this study, the amount corresponds to $171 \mathrm{~g}$ of NMC cathode material.

\subsubsection{System Boundaries and Cut-Off Criteria}

Figure 2 shows the system boundaries which define the valid assessment space for the LCA of the waterjet-based TB recycling. This system represents a gate-to-gate constellation, because only the production of the recyclate cathode material is considered [27]. Impacts on an environmental balance can be distributed as a result of by-products recovered through a recycling process, such as metals from the battery housing and others. Those impacts are resulting from primary extractions, which could be avoided for the materials of those by-products. Therefore, credits can be distributed to this extent, which usually leads to a positive impact on the environmental balance [27]. In this LCA, by- products of the battery are not further treated or evaluated. Since no credits are to be collected for the LCIA for the resulting by-products, their further treatments are outside the system boundary. The same applies to transport and waste treatments. The remaining electrical energy from the TBs is not considered, and therefore leaves the system boundary. Thus, the system boundaries only include the environment of the battery recycling plant. The geographical boundaries of this system are defined as Germany. The time frame of the study is set to the publication date of this study. For this study, in terms of mass, energy, or environmental relevance, no cut-off criteria are set.

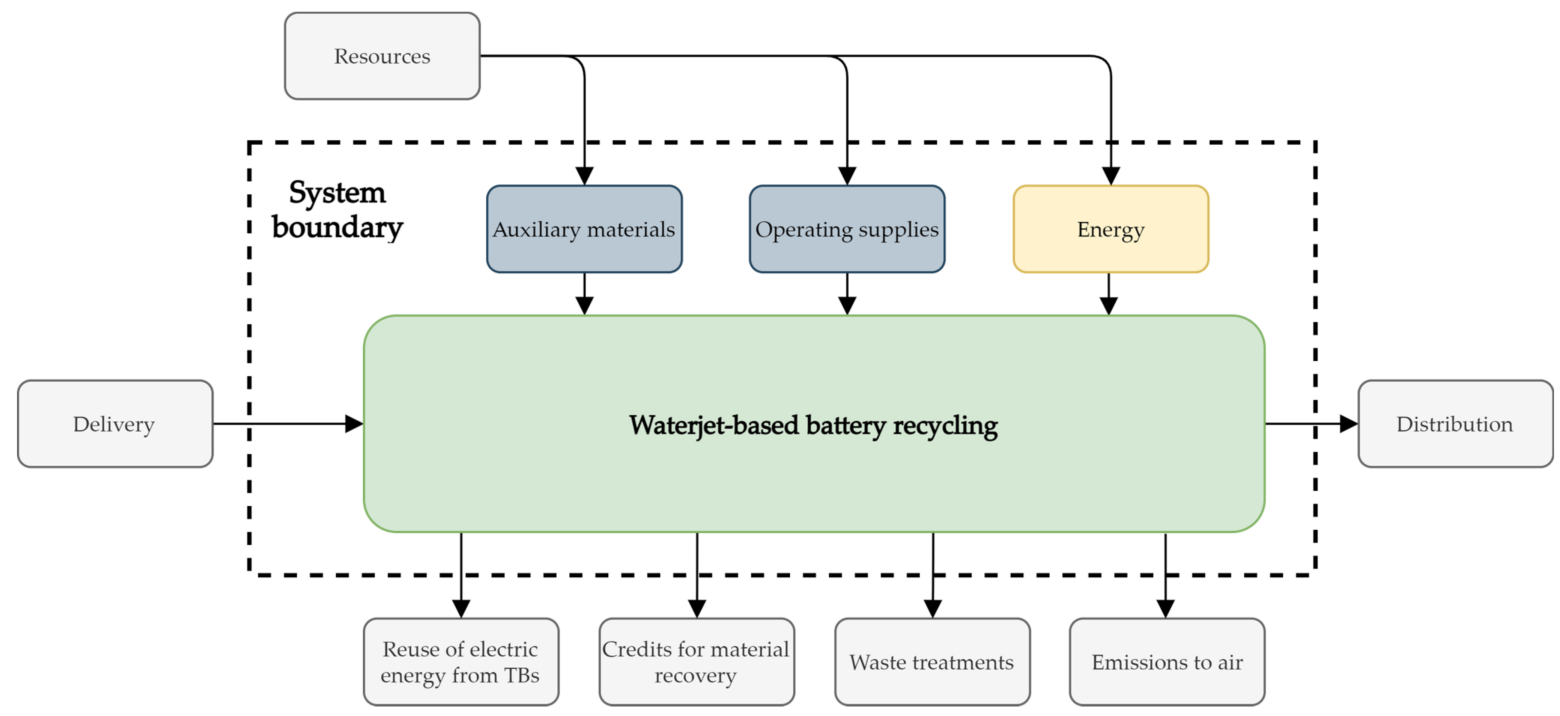

Figure 2. System boundaries of the life cycle assessment (LCA) for the waterjet-based direct traction batteries (TBs) recycling process. Processes outside of the system boundary are not included in this study.

\subsubsection{Method of Impact Assessment}

The LCI of this ecological study is evaluated according to the CML2001 method [28]. The CML method is an impact-oriented approach that assigns the data of the LCI to the environmental impacts. This multidimensional approach aims at the direct material and 
energetic allocation of all impact flows between the environment and the production system [29]. In this study, only the impact category of the GWP, measured in $\mathrm{kg} \mathrm{CO}_{2}$ equivalents $\left(\mathrm{CO}_{2} \mathrm{e}\right)$, is discussed, and evaluated.

\subsubsection{Types and Sources of Data}

For modelling, various LCA data sources such as primary and secondary data were used. For the energy demand and the amount of auxiliary and operating materials required, primary data were available from the pilot plant in operation at the industrial partner's site. Generic data sets from the GaBi balancing software were used for modelling the auxiliary and operating materials as well as the energy supply. For material quantities, for which no primary data were available, reasonable assumptions were made.

To represent the material flows of the individual battery components, data on the battery composition were required; the material composition of the battery was taken from the LithoRec II study [30], a generic battery composition, which was developed by a consortium of various battery manufacturers and other experts within the framework of that project. This battery composition represented the average battery composition commonly used at that time and is shown in Table 1. As this battery composition was also used in other projects, the comparability of the different recycling approaches was simplified [30].

Table 1. Generic battery composition created by expert panels within the LithoRec II study. The battery composition is intended to represent an average traction battery at this time. The battery contains $\mathrm{LiNi}_{x} \mathrm{Mn}_{y} \mathrm{Co}_{z} \mathrm{O}_{2}(\mathrm{NMC})$ cells and $\mathrm{LiPF}_{6}$ as the electrolyte [30].

\begin{tabular}{ccc}
\hline Complete Battery & $\mathbf{1 0 0} \%$ \\
\hline Cathode & $\mathbf{2 5 . 2 \%}$ \\
\hline Manganese & $7.4 \%$ \\
\hline Lithium & $1.2 \%$ \\
\hline Cobalt & $1.0 \%$ \\
\hline Nickel & $2.0 \%$ \\
\hline Aluminium & $6.2 \%$ \\
\hline Oxygen & $5.5 \%$ \\
\hline Others & $1.9 \%$ \\
\hline Anode & $\mathbf{2 0 . 4 \%}$ \\
\hline Separator & $\mathbf{4 . 4 \%}$ \\
\hline Electrolyte & $\mathbf{9 . 6 \%}$ \\
\hline Cell housing & $\mathbf{5 . 1 \%}$ \\
\hline Pack and Module & $\mathbf{3 4 . 7 \%}$ \\
\hline Others & $\mathbf{0 . 6 \%}$ \\
\hline
\end{tabular}

\section{Life Cycle Inventory (LCI)}

\subsection{Waterjet-Based Recycling: Process Description}

This process for recycling TBs is a direct recycling process that aims to recover the electrode coatings of a lithium-ion cell and is currently being practiced in a pilot plant of the industrial DeMoBat project partner Erlos GmbH. In addition to $\mathrm{LiNi}_{\mathrm{x}} \mathrm{Mn}_{\mathrm{y}} \mathrm{Co}_{\mathrm{z}} \mathrm{O}_{2}(\mathrm{NMC})$ cells, other cell chemistries with liquid electrolytes are processable with this recycling approach. The recycling process is described below using an NMC cell with a liquid electrolyte. The stoichiometry of the cathode coating is irrelevant and the NMC material recovered by this approach should subsequently be able to be used directly to produce new TBs. To clarify whether this is possible or not is currently being investigated as part of the DeMoBat project. The graphite of the anode can also be recovered, but in this case is 
not. Due to the usual cathode material recovery rate of at least $90 \%$, or usually higher, this value has been used for this LCA. The other battery components can be recovered almost completely, except for the electrolyte, as this is not treated and therefore not recovered. In Figure 3, the waterjet-based recycling process flow is illustrated with its material input flows. Material flows leaving the process are not shown, due to the defined system boundary. The waterjet-based recycling process can be divided into six process steps as shown in Figure 3, which shows the energy, compressed air, and cathode material flows. Most of the process steps are automated and some are carried out manually. The entire recycling process requires $0.486 \mathrm{MJ}$ of electrical energy for processing $1 \mathrm{~kg}$ of TBs.

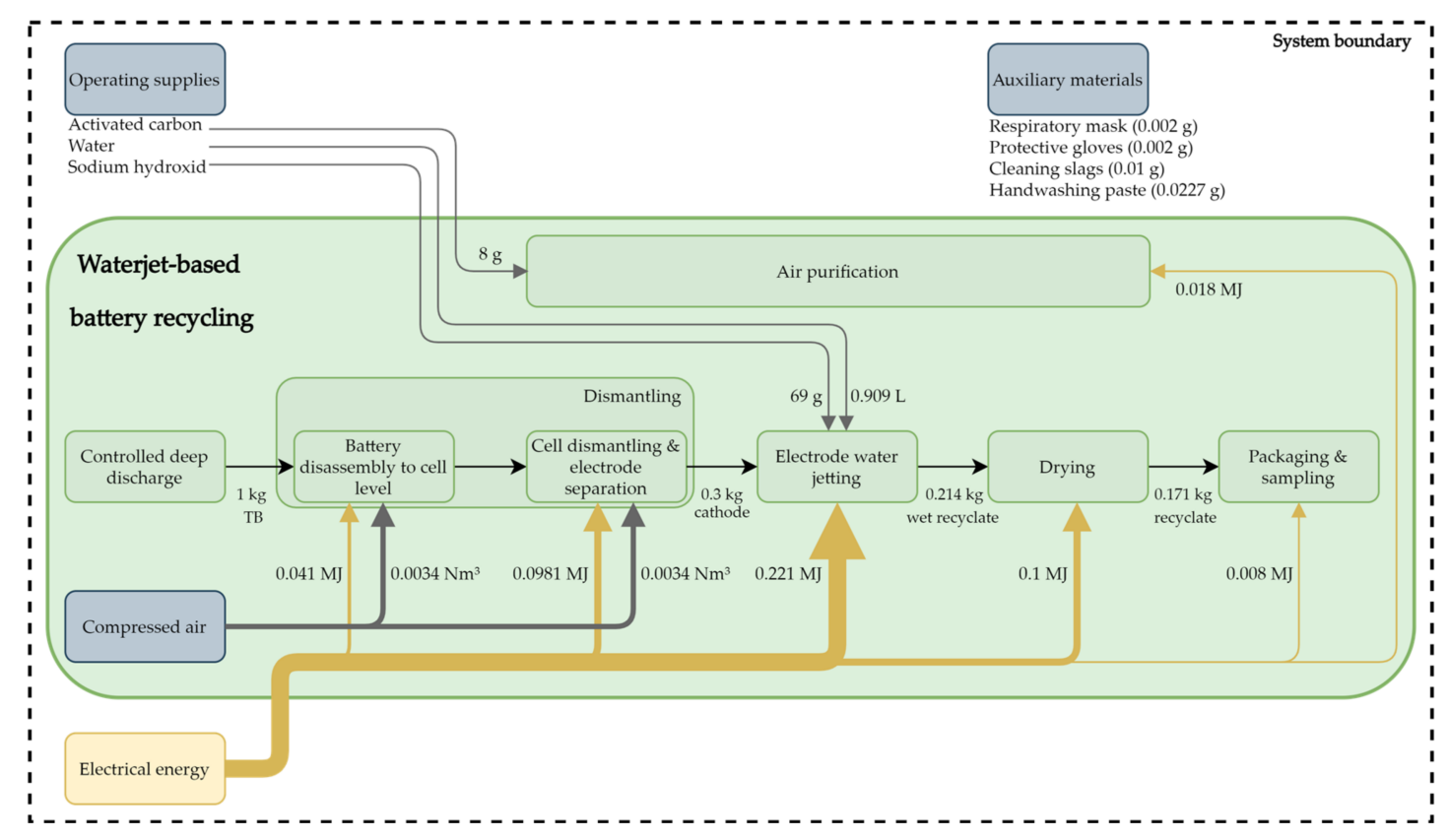

Figure 3. Process flow chart with material input flows and route of the recyclate, with $1 \mathrm{~kg}$ of traction batteries as the initial value.

When delivered, the TBs are opened manually and completely deep discharged. In this step, electrical energy recovered by the deep discharge can be fed into the production grid. To minimize the dangers posed by TBs, they remain short-circuited for $24 \mathrm{~h}$.

After the step of complete deep discharge, the TBs are manually dismantled to the cell level and the separated components, such as the battery housing, the cooling system, the electric and electronics are fed into the usual recycling channels. The energy required for dismantling is low, as it is largely carried out manually at the present time. After removal of the modules, the cells can be separated individually from the battery modules, and, due to the manual disassembly, this step is not energy-intensive. The required energy is allocated to pneumatic, electric power tools and the production environment. Since the compressed air requirement cannot be divided more concretely, it is divided equally between the two sub-process steps of dismantling, as shown in Figure 3. Then, these cells are automatically opened and further disassembled using different methods, depending on the cell typ. In pouch cells, the electrodes and the separator are usually stacked, while in prismatic cells, a stack of cathode, separator, and anode is rolled up. This step is mainly automated. During the cell disassembly, there is no direct treatment of the electrolyte and therefore, some of the electrolyte is trapped in the activated carbon filter.

Since the saturated activated carbon filter is not desorbed in the pilot plant, these materials are replaced regularly. The gases obtained through the opening of the cell, the water jetting, and the drying are captured by a permanent suction system, filtered by activated carbon, and released into the air. 
After separation of these components, the anode and cathode are each fed separately into the electrode decoating process. Separating the anode and the cathode significantly increases the purity of the recyclate and eliminates the need of inerting the process, and therefore leads to energy and cost savings. The decoating of the electrodes is primarily a mechanical removal of the electrode coatings with the aid of a water jet, where the anode and cathode are passed through this process step separately, and this is described as water jetting.

High-pressure water jetting processes are being used more and more [31]. The possible applications include cleaning processes, decoating processes, cutting processes and others [32]. When the water flows through the nozzle, the pressurised flowing water is accelerated. The radius of the water jet becomes larger the further the nozzle is positioned from the target. In addition, the water jet speed decreases with increasing distance from the nozzle. This enables using waterjet processes for various applications. For cutting processes using a waterjet, the distance between the nozzle and the target workpiece is kept small, while decoating processes are carried out at a greater distance. This is because as the distance to the workpiece increases, the difference in jet speed between the center of the water jet and the outer edge of the water jet decreases. In this way, a more consistent removal result can be achieved over a larger area [32].

For this process step, the entire electrode is placed on a conveyor belt, which moves at a constant speed through a washing system. In this washing system, a water jet removes the coating from the cathode and anode collector foil. This process water circulates within the washing system and is rarely exchanged, which is why the total water requirement can be classified as low. During this process, the coating material sediments in the catch basin of the washing system can be recovered by filtration. No special temperature is required for water jetting of the electrodes, therefore, this process step is carried out at room temperature. The remaining electrolytes in the coatings of anode and cathode are washed out during the water jetting, thus, they mix with the process water. Those remaining electrolytes cause the process water to become acidic, which is neutralized by adding sodium hydroxide $(\mathrm{NaOH})$. Since the $\mathrm{pH}$ value of process water is kept in a slightly basic range, the amount of $\mathrm{NaOH}$ required depends on the $\mathrm{pH}$ value of the process water. This process step is highly automated, and it is the most energy-intensive process step in this recycling process. In addition to the electrode coating, the water jetting process also recovers the carrier foil, which can then also be specifically recycled.

Then, the recovered electrode material is dried in an oven for $3 \mathrm{~h}$. Dust produced in the process step is also treated by an air purification system. Packaging and sampling are the final steps in the process chain which require the least amount of energy. In this step, the recyclate is ground to a desired particle size and examined according to its composition. The amount of recovered cathode or anode coating depends mainly on the processed TBs, as there are differences in coating thickness and resistance to water jetting.

\subsection{Greenhouse Gases and Cumulative Energy Consumption}

Figure 4 shows the LCI of the described process flow with a selection of greenhouse gases, particulate matter (PM10), the cumulative energy consumption, and the water consumption, each subdivided into the different process steps. A cumulative energy input (primary energy demand from regenerative and non-regenerative resources) of 3.3 MJ is calculated. As shown in Figure 4, water jetting and air purification are the most energy-intensive process steps, and they are also the biggest emitters of NMVOCs, methane, carbon dioxide, and nitrogen oxides. A closer look at the water jetting step reveals that both $\mathrm{NaOH}(50 \%)$ and the necessary electrical energy are the biggest contributors to gas emissions. For the entire recycling process, a water consumption of $4.6 \mathrm{~L}$ could be determined, and water jetting has the largest share of water consumption among all process steps, with approximately $3 \mathrm{~L}$. Although this recycling approach is a waterjet-based process, the water consumption required for water jetting plays only a minor role, with $0.909 \mathrm{~L}$. The remaining water consumption is mainly attributable to the provision of electric 
energy and the $\mathrm{NaOH}$. The relatively high impacts of the air purification process step for many emissions are mainly attributable to the filter material (activated carbon), while the necessary energy consumption is less decisive. For the nitrous oxide and fluorinated and chlorinated hydrocarbons, more than $50 \%$ of the emitted gas belong to the water jetting step, because of its high energy consumption. The second largest contributor is dismantling, which is due to the high energy requirements and the necessary protective equipment, such as gloves and respiratory protection, as shown in Figure 4. Since sampling and packaging only require a very small amount of electrical energy, this step produces up to $1 \%$ of the emitted gases, which is the lowest share as compared with other steps.

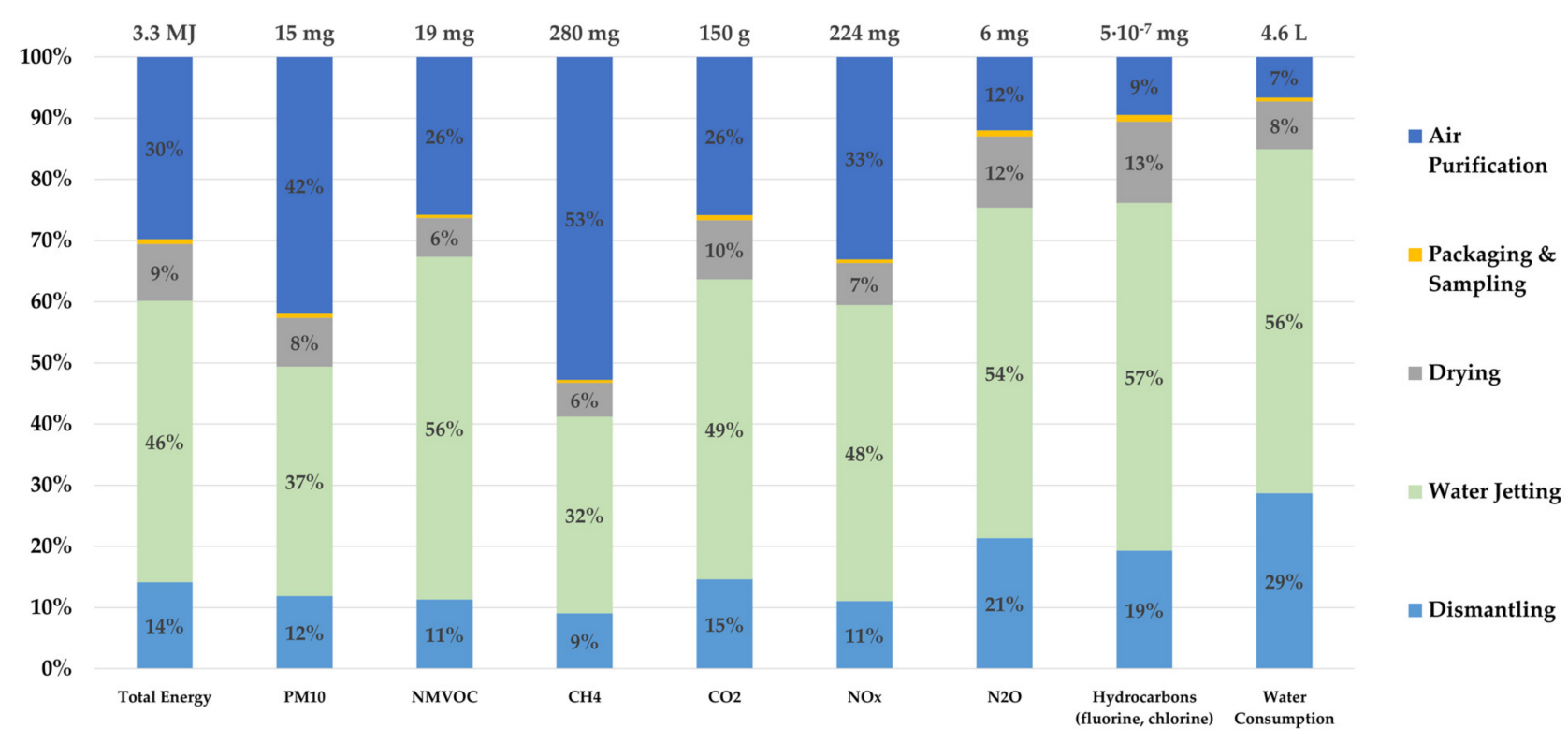

Figure 4. Life cycle inventory (LCI) with selected emissions and cumulative energy consumption of the waterjet-based recycling with the functional unit of $1 \mathrm{~kg}$ traction batteries. Amounts smaller than $1 \%$ are not shown.

\section{Life Cycle Impact Assessment: Global Warming Potential (LCIA-GWP)}

A GWP of $158 \mathrm{~g} \mathrm{CO}_{2} \mathrm{e}$ is calculated for the entire recycling process of $1 \mathrm{~kg}$ of TBs. This implies that the recovery of $171 \mathrm{~g}$ of NMC cathode material with the recycling process described here results in the abovementioned GWP $\left(158 \mathrm{~g} \mathrm{CO}_{2} \mathrm{e}\right)$ or $924 \mathrm{~g} \mathrm{CO}_{2} \mathrm{e}$ for recycling of $1 \mathrm{~kg}$ NMC active material with the battery composition shown in Table 1 . Figure 5 shows the LCIA, and thus presents the GWP of the entire process for $1 \mathrm{~kg}$ of the TBs. The largest share of the GWP is attributable to the water jetting step, which emits $76 \mathrm{~g} \mathrm{CO}_{2} \mathrm{e}$ for the defined functional unit and thus causes $48 \%$ of the total process and the lowest share of the GWP, which is $1 \mathrm{~g} \mathrm{CO}_{2} \mathrm{e}(<1 \%)$, belonging to the packaging and sampling step. The water used for water jetting contributes only a small share (approximately $1.5 \mathrm{~g} \mathrm{CO}_{2} \mathrm{e}$ or $2 \%$ of the water jetting step). Two other factors, the electrical energy required for water jetting the electrodes and $\mathrm{NaOH}(50 \%)$, contribute significantly to the GWP with shares of 30 and $41 \mathrm{~g} \mathrm{CO}_{2} \mathrm{e}$, respectively. In the case of air purification, which is the second largest emitter of greenhouse gases with $27 \%$ of the whole process, the required electrical energy causes approximately $3 \mathrm{~g} \mathrm{CO}_{2} \mathrm{e}(7 \%)$ of the GWP, while the remaining $40 \mathrm{~g} \mathrm{CO}_{2} \mathrm{e}(93 \%)$ is due to the filter medium, which is the activated carbon. The drying oven is powered by electricity, which is why this is fully responsible for the GWP in this process step, with a share of $9 \%$ of the whole recycling process. In the packaging and sampling step, there are no emitters of greenhouse gases, except the electrical energy, which leads to a share of $1 \%$ of the total process. 


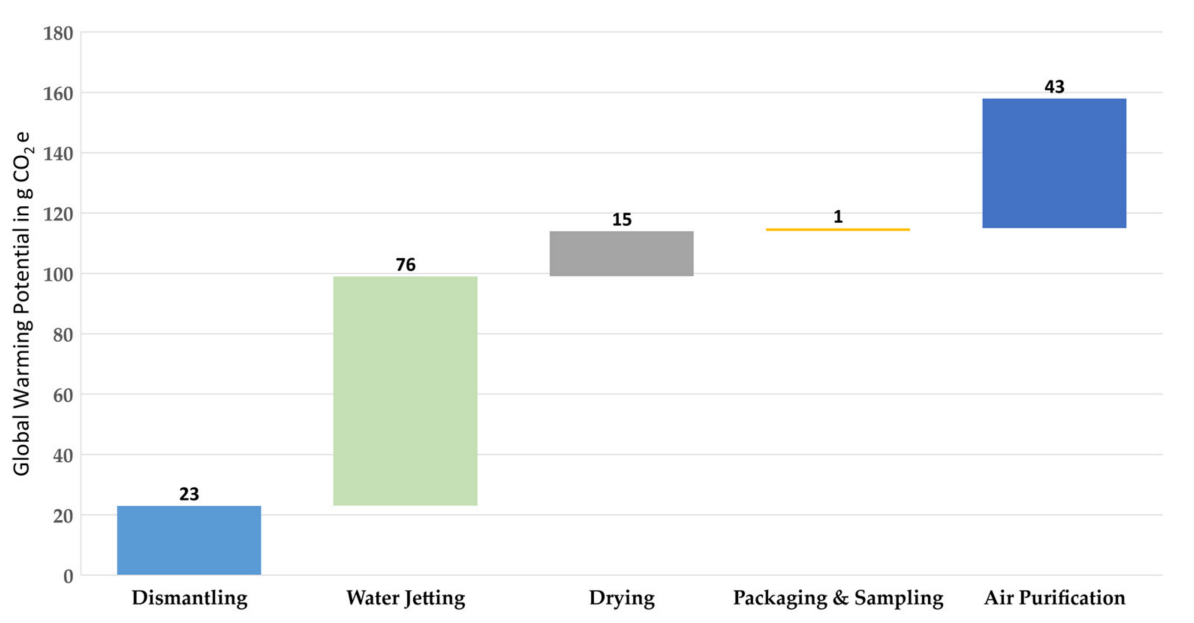

Figure 5. Life cycle impact assessment (LCIA) as the breakdown of the global warming potential according to the process steps of the waterjet-based recycling method for $1 \mathrm{~kg}$ of traction batteries.

\section{Life Cycle Evaluation}

\subsection{Comparison between Systems}

It is reasonable to compare this waterjet-based recycling approach with the recycling processes presented by Buchert et al., namely LithoRec II, EcoBatRec and LiBRi [30,33,34], however, the comparability of the systems should be ensured beforehand or the differences should be considered. By considering the scope definitions, because of differences in the system boundaries, it is difficult to compare the different systems. One of these differences is based on the studies by Buchert et al. [30,34] that evaluated material flows which leave the system boundary via credits, which was deliberately omitted in this study. Table 2 shows the pure direct debits from the cited studies. It is worthwhile mentioning that, in this study, transportation was considered, and therefore, debits for transportation of TBs are not included in the values presented here. More important than the comparison of the abovementioned methodological framework conditions, is the function of these recycling approaches. This is because the recyclates from the LithoRec II, EcoBatRec and LiBRi processes are not comparable with the recyclate from the recycling process presented here. By comparing the LithoRec II process and this waterjet-based recycling process, the differences are clearer. As described in Section 3.1, this waterjet-based recycling process separates cathode coating from the rest of the cell and aims to proportionately add the obtained recyclate directly to a new cathode coating. In contrast, the products of the LithoRec II process are nickel, manganese and cobalt in a sulphate solution, and lithium as lithium hydroxide [30], which can be used again for cathode coating production.

Table 2. A comparison of the global warming potential (GWP) and the cumulative energy consumption of different recycling approaches using the functional unit of $1 \mathrm{~kg}$ of traction batteries. The system boundaries are adjusted to each other.

\begin{tabular}{ccc}
\hline Studies & GWP & Cumulative Energy Consumption \\
\hline LiBRi (indirect recycling) [33] & $4.248 \mathrm{~kg} \mathrm{CO}_{2} \mathrm{e}$ & $61.3 \mathrm{MJ}$ \\
\hline EcoBatRec (indirect recycling) [34] & $1.282 \mathrm{~kg} \mathrm{CO}_{2} \mathrm{e}$ & $14.5 \mathrm{MJ}$ \\
\hline LithoRec II (indirect recycling) [30] & $2.133 \mathrm{~kg} \mathrm{CO}_{2} \mathrm{e}$ & $35.5 \mathrm{MJ}$ \\
\hline DeMoBat (direct recycling) & $0.158 \mathrm{~kg} \mathrm{CO}_{2} \mathrm{e}$ & $3.3 \mathrm{MJ}$ \\
\hline
\end{tabular}

Therefore, the comparison in Table 2 must be considered carefully and is not intended to be a benchmark, but rather to highlight the possible advantages of a direct recycling process as compared with the indirect recycling route. Buchert et al. [30,33,34] focused on indirect battery recycling that used pyrometallurgical or hydrometallurgical processes 
to recover the raw materials of the cathodes, which contributed the most to the GWP of these recycling processes. In the LithoRec II process, hydrometallurgical processing caused about $70 \%$ of the total GWP of this process, while in the LiBRi process, the pyrometallurgical process step and the slag preparation caused 77\% of the total GWP [33]. The biggest driver in the EcoBatRec study was mechanical treatment with $33 \%$, however, the product of the EcoBatRec recycling approach required further treatment, for example by the hydrometallurgical process as used in the LiBRi approach [34].

\subsection{Comparison between Products}

The benefits of this method of adding recovered battery-grade cathode material to the new NMC active material up to a certain proportion are that almost the entire production chain of new cathode coating can be avoided for this proportion, and furthermore, the mining of primary raw materials is not necessary to this extent. While the DeMoBat project determines whether such an approach is possible and, if so, up to what proportion admixtures can be realised without having to record too great a loss of quality in the product (new traction batteries), this study quantifies the possible savings for the GWP of cathode coatings through this procedure.

Since significant production steps to produce cathode coating from primary materials could be neglected, a comparison of the active material recycled in the way described here with cathode coating from primary production is reasonable. Accardo et al. [35] claimed that the stoichiometric composition of the NMC materials played a minor role for the GWP, which was why, in this study, only the addition of recyclate to NMC111 material is illustrated. Dai et al. [36] reported a GWP of $16.1 \mathrm{~kg} \mathrm{CO}_{2}$ e for $1 \mathrm{~kg}$ of NMC111 cathode material [36], which is 100 times higher GWP potential than the cathode material (recyclate) obtained through the waterjet-based battery recycling. The savings that can be achieved by blending different mass fractions of recyclate to the primary cathode material are described in Figure 6, which shows that blending $10 \%$ and $20 \%$ recyclate can save $9.3 \%$ and $18.6 \%$ $\mathrm{CO}_{2} \mathrm{e}$, respectively. Due to the very low GWP of the recyclate, the GWP of the cathode material can be reduced by approximately the same percentage as the recyclate content. The NMC111 cathode material studied by Dai et al. [36] has a share of about $40 \%$ in the GWP of the entire TB, which makes it possible to estimate the impact of the admixture for the GWP of the entire battery. Consequently, the GWP of a traction battery with NMC111 cells can be reduced by $4-8 \%$ by blending the abovementioned proportions. While Accardo et al. [35] illustrated that there are no significant differences in the GWP of different NMC compositions, at the same time, their study also showed that NMC111 material has the highest GWP, which suggests that the savings shown in Figure 6 represent the highest possible savings among the cathode coatings NMC111, NMC622, and NMC811.

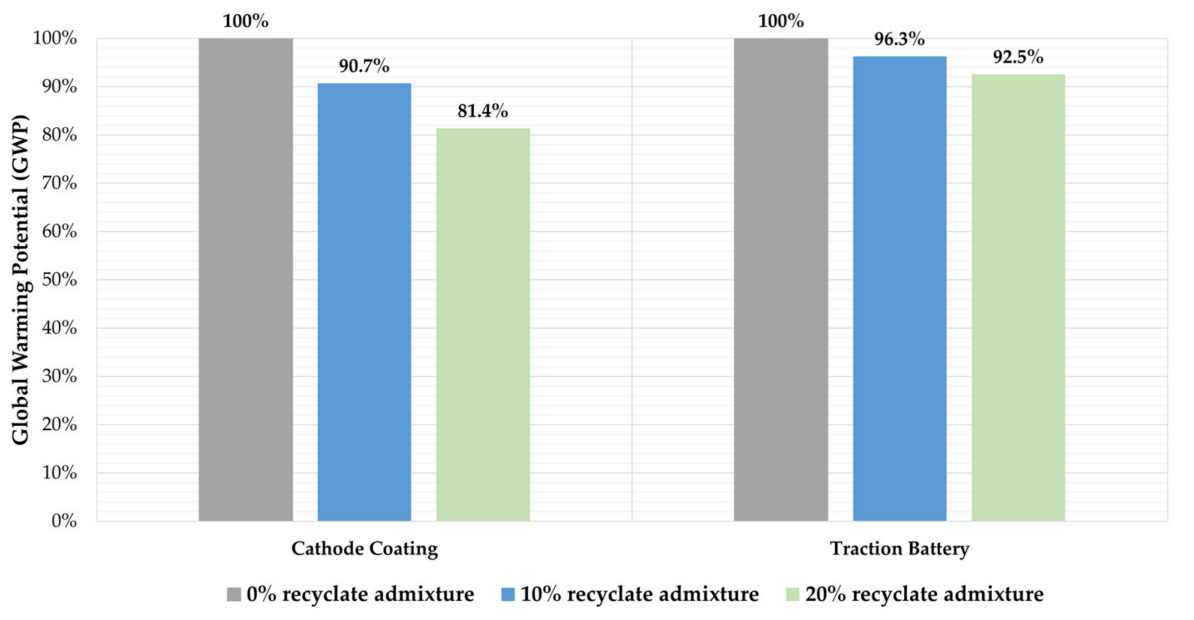

Figure 6. Impact of recyclate admixture in different proportions on the GWP of NMC111 cathode material and the production stage of a traction battery. 


\section{Conclusions}

In this study, a new waterjet-based recycling process for traction battery cells is presented. This direct recycling process detaches the cathode material of a battery cell from the carrier foil with the aid of a water jet. An advantage of this procedure over indirect approaches is that the recovered recyclate can be mixed with new cathode material directly, and therefore energy-intensive manufacturing steps for the admixed fraction can be saved. In addition, the cells or modules are not shredded or melted down, as in conventional recycling processes, but are dismantled to the cellular level, and therefore the pure battery components can be separated by type.

Furthermore, the waterjet-based recycling approach was ecologically evaluated with the help of a life cycle assessment (LCA). The aim is to evaluate its potential ecological performance as compared with indirect recycling approaches and virgin cathode material with the focus on global warming potential (GWP). The results from this study provide an initial assessment of the ecological performance of this recycling approach. A comparison with indirect recycling processes shows that the GWP associated with indirect recycling of traction batteries (TBs) can be reduced by a factor up to 26 through substitution with this direct recycling approach. Compared to cathode coating from production with primary raw materials, the recyclate obtained through the waterjet-based recycling process shows 100 times less GWP. Consequently, the GWP of new battery cells can be significantly reduced through admixture of recyclate obtained through the waterjet-based recycling process. The data basis of the water-based recycling process for the LCA is consistent, as the data are provided first-hand from the recycling company. However, a critical review of the life cycle analysis in this study shows that with the focus on recycling the cathode material, the further battery components are not included. They should be added to the assessment scope in upcoming LCAs to gain a holistic picture of the ecological performance of this process.

From an ecological point of view, the waterjet-based recycling approach can be classified as more environmentally friendly than conventional hydro- or pyrometallurgical recycling processes. Due to the effective ecological performance of this recycling approach, the technical limits should be explored and tested. It also needs to be clarified whether the process can be used for future cell chemistry to fully exploit the given potential of this recycling approach in the long term.

Author Contributions: Conceptualization, F.R. and R.W.; methodology, F.R., I.K.; software, L.K.; validation, A.S., F.R.; formal analysis, I.K. and F.R.; investigation, M.S., M.F. and F.R.; resources, M.S. and R.W.; data curation, M.S. and L.K.; writing-original draft preparation, L.K. and M.F.; writing-review and editing, F.R. and I.K; visualization, F.R. and L.K.; supervision, R.W., F.R. and A.S.; project administration, R.W. and I.K.; funding acquisition, R.W. and L.K. All authors have read and agreed to the published version of the manuscript.

Funding: The authors wish to thank the Ministry of the Environment, Climate Protection and the Energy Sector Baden-Wuerttemberg for funding this work under the funding code L7520105 as part of the joint project "DeMoBat". The article processing charge was funded by the Baden Wuerttemberg Ministry of Science, Research and the Arts and the Hochschule Esslingen-University of Applied Sciences in the funding program Open Access Publishing.

Institutional Review Board Statement: Not applicable.

Informed Consent Statement: Not applicable.

Data Availability Statement: The data presented in this study are available on reasonable request from the corresponding author.

Conflicts of Interest: The authors declare no conflict of interest.

\section{References}

1. Reddy, T.B. Linden's Handbook of Batteries, 4th ed.; Linden, D., Ed.; McGraw-Hill: New York, NY, USA, 2011 ; ISBN 9780071624213.

2. Tarascon, J.M.; Armand, M. Issues and challenges facing rechargeable lithium batteries. Nature 2001, 414, 359-367. [CrossRef] [PubMed] 
3. Velázquez-Martínez, O.; Valio, J.; Santasalo-Aarnio, A.; Reuter, M.; Serna-Guerrero, R. A Critical Review of Lithium-Ion Battery Recycling Processes from a Circular Economy Perspective. Batteries 2019, 5, 68. [CrossRef]

4. Pillot, C. The Rechargeable Battery Market and Main Trends 2014-2025. In Proceedings of the 31st International Battery Seminar \& Exhibit, Nica, France, 6 October 2015.

5. Kosai, S.; Takata, U.; Yamasue, E. Natural resource use of a traction lithium-ion battery production based on land disturbances through mining activities. J. Clean. Prod. 2021, 280, 124871. [CrossRef]

6. Gaines, L. The future of automotive lithium-ion battery recycling: Charting a sustainable course. Sustain. Mater. Technol. 2014, 1-2, 2-7. [CrossRef]

7. Bernardes, A.M.; Espinosa, D.C.R.; Tenório, J.A.S. Recycling of batteries: A review of current processes and technologies. J. Power Source 2004, 130, 291-298. [CrossRef]

8. EBRA. Noticeable Growth of the Quantity of Batteries Recycled; European Battery Recycling Association: Brussels, Belgium, 2012.

9. Wang, Y.; An, N.; Wen, L.; Wang, L.; Jiang, X.; Hou, F.; Yin, Y.; Liang, J. Recent progress on the recycling technology of Li-ion batteries. J. Energy Chem. 2020, 55, 391-419. [CrossRef]

10. Steward, D.; Mayyas, A.; Mann, M. Economics and Challenges of Li-Ion Battery Recycling from End-of-Life Vehicles. Proc. Manuf. 2019, 33, 272-279. [CrossRef]

11. European Commission. Proposal for a Regulation of the European Parliament and of the Council Concerning Batteries and Waste Batteries, Repealing Directive 2006/66/EC and Amending Regulation (EU) No 2019/1020. Available online: https: / / ec.europa.eu/environment/waste/batteries/pdf/Proposal_for_a_Regulation_on_batteries_and_waste_batteries.pdf (accessed on 17 February 2021).

12. Boyden, A.; Soo, V.K.; Doolan, M. The Environmental Impacts of Recycling Portable Lithium-Ion Batteries. Proc. CIRP 2016, 48, 188-193. [CrossRef]

13. Gao, W.; Zhang, X.; Zheng, X.; Lin, X.; Cao, H.; Zhang, Y.; Sun, Z. Lithium Carbonate Recovery from Cathode Scrap of Spent Lithium-Ion Battery: A Closed-Loop Process. Environ. Sci. Technol. 2017, 51, 1662-1669. [CrossRef]

14. Zhan, R.; Payne, T.; Leftwich, T.; Perrine, K.; Pan, L. De-agglomeration of cathode composites for direct recycling of Li-ion batteries. Waste Manag. 2020, 105, 39-48. [CrossRef]

15. Chen, M.; Ma, X.; Chen, B.; Arsenault, R.; Karlson, P.; Simon, N.; Wang, Y. Recycling End-of-Life Electric Vehicle Lithium-Ion Batteries. Joule 2019, 3, 2622-2646. [CrossRef]

16. Gao, R.; Sun, C.; Xu, L.; Zhou, T.; Zhuang, L.; Xie, H. Recycling LiNi0.5Co0.2Mn0.3O2 material from spent lithium-ion batteries by oxalate co-precipitation. Vacuum 2020, 173, 109181. [CrossRef]

17. Sieber, T.; Ducke, J.; Rietig, A.; Langner, T.; Acker, J. Recovery of Li(Ni0.33Mn0.33Co0.33) $\mathrm{O}_{2}$ from Lithium-Ion Battery Cathodes: Aspects of Degradation. Nanomaterials 2019, 9, 246. [CrossRef]

18. Larouche, F.; Tedjar, F.; Amouzegar, K.; Houlachi, G.; Bouchard, P.; Demopoulos, G.P.; Zaghib, K. Progress and Status of Hydrometallurgical and Direct Recycling of Li-Ion Batteries and Beyond. Materials 2020, 13, 801. [CrossRef]

19. Zang, G.; Zhang, J.; Xu, S.; Xing, Y. Techno-economic analysis of cathode material production using flame-assisted spray pyrolysis. Energy 2021, 218, 119504. [CrossRef]

20. Gaines, L. Lithium-ion battery recycling processes: Research towards a sustainable course. Sustain. Mater. Technol. 2018, 17, e00068. [CrossRef]

21. Sloop, S.E.; Crandon, L.; Allen, M.; Lerner, M.M.; Zhang, H.; Sirisaksoontorn, W.; Gaines, L.; Kim, J.; Lee, M. Cathode healing methods for recycling of lithium-ion batteries. Sustain. Mater. Technol. 2019, 22, e00113. [CrossRef]

22. Doose, S.; Mayer, J.K.; Michalowski, P.; Kwade, A. Challenges in Ecofriendly Battery Recycling and Closed Material Cycles: A Perspective on Future Lithium Battery Generations. Metals 2021, 11, 291. [CrossRef]

23. Deutsches Insitut für Normung e.V. Umweltmanagement—Ökobilanz_Grundsätze und Rahmenbedingungen; Beuth Verlag GmbH: Berlin, Germany, 2009.

24. Deutsches Insitut für Normung e.V. Umweltmanagement-Ökobilanz-Anforderungen und Anleitungen; Beuth Verlag GmbH: Berlin, Germany, 2006.

25. Ministerium für Umwelt, Klima und Energiewirtschaft Baden-Württemberg. Umweltminister Franz Untersteller Überreicht Förderbescheide für Demontagefabrik "DeMoBat" in Höhe von 13 Millionen Euro; Ministerium für Umwelt, Klima und Energiewirtschaft Baden-Württemberg: Stuttgart, Germany, 2020.

26. Sphera Solutions, Inc. GaBi Manual. Available online: http://www.gabi-software.com/fileadmin/GaBi_Manual/GaBi_6_ manual.pdf (accessed on 27 January 2021).

27. European Commission. International Reference Life Cycle Data System (ILCD) Handbook: General guide for Life Cycle AssessmentDetailed Guidance; European Commission: Luxemburg, 2010.

28. Bruijn, H.; Duin, R.; Huijbregts, M.A.J.; Guinee, J.B.; Gorree, M.; Heijungs, R.; Huppes, G.; Kleijn, R.; Koning, A.; Oers, L.; et al. Handbook on Life Cycle Assessment: Operational Guide to the ISO Standards; Kluwer Academic Publishers: Dordrecht, The Netherlands, 2004; ISBN 978-0-306-48055-3.

29. Kaltschmitt, M.; Schebek, L. Umweltbewertung für Ingenieure: Methoden und Verfahren; Springer Vieweg: Berlin, Germany, 2015; ISBN 978-3-642-36989-6.

30. Buchert, M.; Sutter, J. Aktualisierte Ökobilanzen zum Recyclingverfahren LithoRec II für Lithium-Ionen-Batterien; Oeko-Institut e.V.: Berlin, Germany; Darmstadt, Germany, 2016. 
31. Momber, A.W. Image processing as a tool for high-pressure water jet coating removal assessment. Int. J. Adv. Manuf. Technol. 2016, 87, 571-578. [CrossRef]

32. Ning, D.; Wang, Q.; Tian, J.; Gong, Y.; Du, H.; Chen, S.; Hou, J. Experimental Study on the Coating Removing Characteristics of High-Pressure Water Jet by Micro Jet Flow. Micromachines 2021, 12, 173. [CrossRef]

33. Buchert, M.; Jenseit, W.; Merz, C.; Schüler, D. Verbundprojekt: Entwicklung Eines Realisierbaren Recyclingkonzepts für die Hochleistungsbatterien Zukünftiger Elektrofahrzeuge—LiBRi: Teilprojekt: LCA der Recyclingverfahren; Oeko-Institut e.V.: Berlin, Germany; Darmstadt, Germany, 2011.

34. Buchert, M.; Sutter, J. Aktualisierte Ökobilanz zum Recyclingverfahren EcoBatRec für Lithium-Ionen-Batterien; Oeko-Institut e.V.: Berlin, Germany; Darmstadt, Germany, 2016.

35. Accardo, A.; Dotelli, G.; Musa, M.L.; Spessa, E. Life Cycle Assessment of an NMC Battery for Application to Electric Light-Duty Commercial Vehicles and Comparison with a Sodium-Nickel-Chloride Battery. Appl. Sci. 2021, 11, 1160. [CrossRef]

36. Dai, Q.; Kelly, J.C.; Gaines, L.; Wang, M. Life Cycle Analysis of Lithium-Ion Batteries for Automotive Applications. Batteries 2019, 5, 48. [CrossRef] 